\title{
Evaluasi Penanganan Stunting Melalui Dana Desa Di Masa Pandemi Covid-19 Dengan Metode Sistematik Review
}

\author{
Retno Dewi Anggraeni ${ }^{1 *}$, Ani Margawati ${ }^{2}$ Nurjazuli $^{3}$ \\ 1,2,3Program Studi Magister Promosi Kesehatan, Universitas Diponegoro, Semarang \\ *shaliretno@gmail.com
}

\begin{abstract}
Stunting is one of the malnutrition issues in Indonesia. The government's efforts in stunting handling were explained in the work plan of the Ministry of Village, Development of Disadvantaged Regions and Transmigration where it visions to act upon SDGs by using the allocated village funds. Specific nutrition intervention can be done by using the village funds for the revitalization of integrated health posts and the community feeding center for babies, children under five, and pregnant women as the first referral facility for malnutrition in a village. Meanwhile, sensitive nutrition interventions deal with the development and reconstruction of sanitation and hygiene, as well as a bridge for the community, woman creative empowerment, activities involving community workers, or enabling works for improving the economic status among the poor in each village. Sensitive nutrition interventions underwent constraints during the COVID-19. Activities in integrated health posts were also hampered due to the community concern of contracting COVID-19. Other hampered specific nutrition interventions included the increasing number of distributed tablets due to the regulation of social restrictions. Not all schools conduct face-to-face teaching and learning processes. During the COVID-19 pandemic, the government prioritizes both specific and sensitive nutrition interventions for stunting handling.
\end{abstract}

Keywords: Village funds, Stunting handling, Covid-19 pandemic

\begin{abstract}
Abstrak
Stunting adalah salah satu permasalah gizi yang terjadi di Indonesia.. Hasil studi menunjukan bahwa pemanfaaatan dana desa sudah mulai diaplikasikan, namun masih perlu disosialisasikan prioritas pemanfaatannya untuk kegiatan penanganan stunting. Upaya pemerintah dalam penaganan stunting tertuang dalam rencana kerja Kementerian Desa Pembangunan Daerah Tertinggal \& Transmigrasi untuk mewujudkan aksi Sustainable Development Goals (SDGs) dengan pemanfaatan dana desa. Intervensi gizi spesifik yang dapat dilakukan dengan pemanfaatan dana desa salah satunya adalah kegitan revitasilasi posyandu, PMT untuk bayi, balita dan ibu hamil, membuat community feeding center (CFC) sebagai tempat rujukan pertama kasus gizi yang ada di dasa, sedangkan intervensi gizi sensitif dengan kegiatan atau program pembangunan dan perbaikan sanitasi air bersih dan jambanisasi untuk masyarakat, kegiatan peningkatan ketrampilan perempuan untuk pemberdayaan perempuan, kegiatan yang melibatkan tenaga kerja masyarakat desa atau padat karya untuk meningkatkan ekonomi masyarakat kurang mampu di masing masing desa. Kegiatan intervensi gizi sensitif sedikit megalami kendala pada awal terjadinya wabah Covid-19, pada saat itu kegiatan posyandu sempat terganggu karena faktor kecemasan masyarakat akan terpapar virus Covid-19. Kegiatan intervensi gizi spesifik lain yang sedikit terganggu yaitu distribusi tablet tambah karena masih ada aturan pembatasan sosial, belum semua sekolah melakukan kegiatan belajar mengajar dengan tatapmuka. Pada masa pandemi Covid-19 pemerintah masih memprioritaskan penanganan stunting baik dengan intervensi gizi spesifik dan sensitif.
\end{abstract}

Kata kunci: Dana Desa; penanganan stunting; pandemi covid-19 


\section{Pendahuluan}

Stunting yaitu suatu kondisi kekurangan gizi kronis oleh karena defisiensi zat gizi mikro dan makro. Pada kasus stunting tinggi badan balita lebih pendek dari usianya [1]. Resiko stunting dapat terjadi dari saat ibu mulai hamil sampai anak usia 2 tahun atau 1000 Harri Pertama Kehidupan (HPK), oleh karena itu periode ini disebut sebagai periode emas dimana pertumbuhan dan perkembangan janin sangat dipengaruhi oleh kondisi ibu.[2] Kondisi Kekurangan Energi Kronik (KEK), ibu anemia dapat menyebabkan kelahiran Bayi Berat Badan Lahir Rendah (BBLR). Pola asuh pemberian makan yang kurang baik juga dapat menjadi penyebab terjadinya stunting, termasuk pada saat pemberian Makanan Pendamping - ASI (MP-ASI) yang tidak mengikuti tahap perkembangan usia anak dan kurangnya kandungan zat gizi dalam MP-ASI, asupan gizi yang kurang kandungan gizi mikro (kalsium, fosfor, vitamin A, zat besi, zink) dan gizi makro (lemak, karbohidrat, protein) kualitas asam amino banyak terdapat pada protein hewani, bayitidak diberi ASI ekslusif, penyakit infeksi pada bayi dan balita dengan durasi dan intensitas kambuhnya penyakit (seperti diare, infeksi parasite)[3][4]. Penyakit infeksi saluran pernafasan atas atau ISPA dengan tingkat kekambuhan dan durasi penyakit yang lama dapat berpeluang untuk terjadinya stunting[5]. Akses air bersih dan sanitasi yang buruk dapat menjadi pemicu terjadinya stunting, termasuk tingkat pendidikan orang tua dan kondisi sosial ekonomi keluarga yang rendah berpengaruh pada kejadian stunting[4][6][7]. Prevalensi stunting pada anak perempuan lebih rendah dari pada anak laki -laki[8]. Dampak stunting jangka pendek yaitu perkembangan otak terhambat, gangguan metabolism glukosa, lipid, protein dan hormon[9]. Efek jangka panjang pada kesehatan dimasa mendatang yaitu risiko obesitas, penyakit diabetes mellitus, jantung, dan menurunnya kemampuan kognitif pada anak[10]. Prevalensi stunting hasil Riskesdas tahun 2018 sebesar 30,8\% dan pada tahun 2019 hasil Survei Status Gizi Balita Indonesia (SSGBI) prevalensi stunting turun menjadi $27,67 \%$ yang artinya penurunan hanya 3,13\%.[11]. Pemerintah sendiri mentargetkan penurunan angka stunting $14 \%$ pada tahun 2024. Prioritas pembangunan nasional yang tertuang dalam Rencana pembangunan Jangka Menengah Nasional (RPJMN) 2019-2024 yaitu mewujudkan SDM yang berkualitas dan berdaya saing tinggi. Indikator SDM yang berkualitas salah satunya adalah menurunnya angka prevalensi stunting[12]. Upaya yang dilakukan pemerintah dalam penurunan stunting yaitu dengan pemanfaatan dana desa. Prioritas pemanfaatan dana desa salah satunya adalah untuk pencegahan dan penanganan stunting. Kebijakan pemerintah untuk percepatan perunrunan stunting yaitu; dengan intervensi gizi spesifik dan sensitif. Intervensi gizi spesifik hanya menyelesaikan $30 \%$ permasalahan gizi stunting, oleh karena itu perlu dilakukan intervensi gizi sensitif yang dapat menyelesaikan $70 \%$. Intervensi gizi sensitif sebagai upaya penanganan stunting dilakukan secara bersama terkoordinasi oleh beberapa sektor[13]. Kegiatan intervensi gizi spesifik dan sensitif menjadi prioritas yang tercantum dalam Permendes. Prioritas intervensi gizi spesifik dan sensitif yang tercantum dalam Permendes antara lain; penigkatan gizi keluarga di posyandu untuk ibu hamil dan balita, pelatihan kader tentang kesehatan, gizi, pendampingan ASI, pentingnya prioritas $1000 \mathrm{HPK}$, peningkatan 


\section{Jurnal Ilmiah Kesehatan}

Vol. 14 No. 2, September 2021, Page 139-151 ISSN : 1978-3167 (Print), 2580-135X (Online)

kesehatan remaja putra dan putri serta pemberian TTD untuk remaja putri, penyediaan akses air bersih dan sanitasi atau jamban yang sehat, peningkatan ketahanan pangan, penyuluhan dan peningkatan akses kesehatan dan KB[14]. Pada lampiran Permendes juga disebutkan untuk penanganan pandemic covid-19, akan tetapi upaya stunting tetap menjadi prioritas. Kondisi pandemic covid-19 sedikit menghambat kegiatan penanganan stunting, namun kegiatan tetap berjalan dengan tetap mematuhi protocol kesehatan, kebijakan pembatasan sosial dikeluarkan oleh pemerintah untuk mencegah penyebaran covid-19.

\section{Metode}

Penelitian ini menggunakan literature review dari beberapa hasil penelitian kriteria artikel yang dipilih sebagai subjek penelitian yaitu intervensi penaganan stunting. Metode yang digunakan sistematik review dengan mengumpulkan artikel - artikel menggunakan beberapa sumber pencairan jurnal melalui google scholar dan science direct dari tahun 2016-2021 dari 20 penelitian berbeda dengan kata kunci penanganan stunting. Analisis dilakukan dengan membandingkan metode penelitian, subjek penelitian, serta variabel yang diteliti yaitu intervensi gizi.

\section{Hasil dan Pembahasan}

\section{Hasil}

Tabel 1. Hasil Analisis Artikel

\begin{tabular}{|c|c|c|c|c|}
\hline No & Sitasi & Metode & $\begin{array}{l}\text { Sampel/ } \\
\text { Tempat }\end{array}$ & Hasil \\
\hline 1 & $\begin{array}{l}\text { Norsanti } \\
\text {,(2021) }\end{array}$ & $\begin{array}{l}\text { Kualitatif, interview, purposive } \\
\text { sampling }\end{array}$ & $\begin{array}{l}\text { Sampel; } 15 \text { orang } \\
\text { Tempat; desa Mampari dan desa } \\
\text { Banua Hanyar, Kecamatan } \\
\text { Batumandi Kabupaten Balangan }\end{array}$ & $\begin{array}{l}\text { Program percepatan penurunan stunting sudah } \\
\text { dilaksanakan oleh puskesmas antara lain; pemberian } \\
\text { tablet tambah darah dan makanan tambahan pada } \\
\text { ibu hamil, imunisasi dasar lengkap, pemberian } \\
\text { vitamin A dan zinc dan pemberian makanan } \\
\text { tambahan pada balita. Kegiatan kader PMT } \\
\text { ( Pemberian Makanan Tambahan ) untuk distribusi } \\
\text { makanan matang kepada balita stunting. Salah satu } \\
\text { faktor penghambatnya yaitu kurangnya pendanaan } \\
\text { atau anggaran untuk kegiatan. Tahun } 2020 \\
\text { anggaran untuk desa Mampiri dan desa Benua } \\
\text { Hanyar hanya difokuskan pada penyediaan barang }\end{array}$ \\
\hline
\end{tabular}


untuk pencegahan penyebaran virus covid-19 dan pemberian bansos, sehingga rencana untuk menambah kegiatan pada program percepatan penurunan stunting menjadi terhambat.[15]

C.Rosha,et

al,

(2016)
Kohort,

kualitatif,

Interview, Purposive sampling
Sampel: 12 orang Programer

Dinkes,

Petugas Gizi Puskesmas, Lurah, Ketua RW, Ketua RT, Posdaya Temapat; Bogor
Tempat;

Kab. Blora
Intervensi gisi spesifik banyak dilakukan sektor Kesehatan; intervensi untuk bayi dan balita dengan pemantauan tumbuh kembang,untuk ibu balita kelas balita,kelas ASI,pemberian tablet tambah darah untuk remaja,prioritas intervensi pada 1000 HPK (Hari Pertama Kehidupan), Intervensi gizi sensitif: peningkatan Kesehatan lingkungan,perbaikan sanitasi, pemberdayaan perempuan, intervensi peningkatan untuk mengatasi kemiskinan[16]

Implementasi kebijakan intervensi gizi sensitif belum optimal yaitu; program Penyediaan Air Minum dan Sanitasi berbasis Masyarakat (PAMSIMAS), Jaminan Kesehatan Nasional (JKN),Program Keluarga Harapan (PKH), Revitalisasi Posyandu. Faktor penghambat intervensi gizi sensitif; Sumber Daya Manusia (SDM) belum memadai secara kualitas dan kuantitas, sumber anggaran terbatas sehingga tidak dapat mencakup semua sasaran masyarakat, kurangnya 
Jurnal Ilmiah Kesehatan

Vol. 14 No. 2, September 2021, Page 139-151 ISSN : 1978-3167 (Print), 2580-135X (Online)

dukungan atau partisipasi dan kesadaran masyarakat untuk pelaksanaan kebijakan dan penerapan pola hidup sehat, intensitas penyebaran kebijakan penurunan stunting belum maksimal.[17]

G.Muthia, et Kualitatif, al (2020) interview, observasi, purposive sampling

Kualitatif, et al (2018)

\section{Sampel;}

Kepala dinas kesehatan, kasi kesga gizi, Kepala Puskesmas, programmer gizi, progamer ibu dan anak, programmer imunisasi,programer promkes, dan ibu balita.

Tempat; Kab. Pasaman

Sampel; DPRD,Bupati, Kabid Sosial Budaya BAPPEDA, Kepala Dinkes,

Kasubag Perencanaan dan Penganggaran Dinkes,Kasi Kesga Gizi Dinkes, Pemegang program Gizi Dinkes, Kasi Kesling
Kegiatan intervensi gizi spesifik berupa kegiatan rutin dari puskesmas yang dilaksanakan dengan dana JKN oleh karena dana BOK terlambat, Sumber Daya Manusia untuk pelaksanaan intervensi gizi spesifik masih kurang, perencanaan kegiatan intervensi gizi spesifik masih sama dengan tahun sebelumnya, Obat dan distribusi untuk stunting serta SOP (Standar Operasional Prosedur) tersedia, intervensi gizi spesifik yang dilakukan berjenjang dari kabupaten ke kecamatan dan desa belum didukung oleh tokoh masyarakat dan dokumen yang lengkap. [18]

Anggaran untuk kegiatan pencegahan stunting belum tersedia, cakupan air bersih $66,15 \%$ target $72 \%$ dan cakupan sanitasi $63,15 \%$ target $100 \%$ masih belum mencapai target, belum ada regulasi khusus terkait stunting. [19] 
Dinkes,Kasi Promkes

Dinkes,Kepala Puskesmas, Pemegang program gizi

puskesmas

\section{Indepth interview,}

studi literatur

7 Prihatini,

Subanda

\section{Kualitatif,Purposive sampling, Triangulasi}

Sampel; 2 desa

Tempat; Kab. Pandeglang
Sampel; Pemerintahan desa (Kepala Desa, Badan

Permusyawaratan Desa atau BPD, masyarakat dan
Hasil analisis; tingginya stunting di Kab. Pandeglang disebabkan pola asuh kurang baik, kurangnya asupan makanan bergizi, pelayanan kesehatan terbatas, kurangnya akses air bersih dan buruknya sanitasi. Upaya yang dilakukan Kab. Pandeglang untuk percepatan penurunan prevalensi stunting dengan kerjasama lintas sektor antara lain;Dinas Pertanian, Dinas Pemberdayaan Masyarakat dan Pemerintahan Desa, Dinas Pemberdayaan Perempuan Perlindungan Anak dan Keluarga Berencana, Dinas Sosial, Dinas Perencanaan dan Pembangunan Daerah dan Kecamatan.untuk melaksanakan program penanganan stunting.[12]

Penggunaan dana desa untuk pencegahan dan penanganan stunting dilakukan dengan tahapan proses penyusunan rencana kegiatan bersama perwakilan masyarakat, aparatur desa dan 
Jurnal Ilmiah Kesehatan

Vol. 14 No. 2, September 2021, Page 139-151 ISSN : 1978-3167 (Print), 2580-135X (Online)

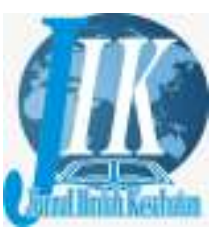

pendamping desa), Kepala

puskesmas,Bidan Desa, Petugas

Gizi puskesmas.

Sampel; Perangkat desa,

Puskesmas Petarukan Badan

Perencanaan Pembangunan

Daerah (BAPPEDA), Dinkes

Pemalang.

Tempat; Desa Kalirandu-

Kecamatan Petarukan.

Sampel; 3 desa pemegang kebijakan bidang kesehatan (Kepala Puskesmas, petugas Gizi, Promkes, Bidan Koordinator). Pada pelaksanaan kegiatan pencegahan stunting selalu koordinasi dengan pihak Puskesmas. Upaya pencegahan stunting melalui dana desa dituangkan dalam Surat Keputusan dan menjadi salah satu syarat pencairan dana desa.[20]

Masih ada ketidakseimbangan sumber daya baik manusia maupun keuangan, partisipasi masyarakat dalam pembentukan kader stunting

masih rendah kader stunting masih banyak dari kader kesehatan sehingga mempunyai tugas ganda. Sudah ada regulasi tentang stunting yaitu Surat Keputusan Bupati tentang pembentukan tim percepatan pencegahan dan penanggulangan stunting yaitu Tim intervensi spesifik dan Tim intervensi sensitif, yang ditindaklanjuti dengan Surat Keputusan Kepala desa tentang pembentukan kader stunting.[21]

Permasalahan terkait koordinasi,pendanaan dan partisipasi dari aparat desa menjadi permasalahan

\footnotetext{
Tempat; 2 desa di Kab. Rokan

, (2020)

kuantitatif,menggali informasi
} 
dengan kualitatif,

interview,observasi

lapangan,diskusi, FGD,

metodologi yang digunakan

mixed method dengan analisis

minimum
Hulu (Verifikasi data stunting ke 6 Puskesmas dan 10 desa lokus, 1 desa di Kab.Kampar

yang terjadi di 2 kabupaten lokus, Pemerintah Rokan Hulu telah melakukan program dan kegiatan intervensi stunting. Provinsi Riau telah melakukan intervensi stunting melalui intervensi spesifik dan intervensi sensitif. Intervensi spesifik sebagian besar berada pada program Dinas Kesehatan, sedangkan intervensi sensitif pada stakeholder lintas sektor baik propinsi maupun kabupaten. Pada level propinsi belum ditemukan adanya koordinasi lintas sektor sehingga program dan kegiatan yang ada berjalan masing - masing dengan sasaran berbeda.[22]

Sampel; 13 Kabupaten prioritas TNP2K atau Tim Nasional Percepatan Penanggulangan Kemiskinan, setiap Kabupaten di pilih 1 kecamatan dengan 2 desa lokus stunting

Sampel; 5 orang konselor PMBA (Pemberian Makanan Tambahan Bayi dan Anak), 2 orang fasilitator PMBA, 5 orang ibu
Belum terjalin koordinasi yang optimal antar lintas sektor baik tingkat propinsi maupun Kabupaten untuk penanganan stunting. [23]

Upaya percepatan pencegahan stunting menetapkan prioritas program 2 intervenis yaitu intervensi gizi spesifik dan intervensi gizi sensitif. Intervensi gizi spesifik dilaksanakan dengan melibatkan lintas 
Jurnal Ilmiah Kesehatan

Vol. 14 No. 2, September 2021, Page 139-151 ISSN : 1978-3167 (Print), 2580-135X (Online)

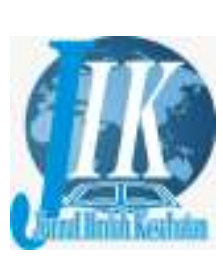

hamil, 5 orang ibu bersalin, 5

orang masyarakat. sektor dengan kegiatan; pelatihan kader dan petugas kesehatan tentang PMBA (Pemberian Makanan Tambahan Bayi dan Anak), kelas ibu hamil, kelas ibu balita, pendiidkan kesehatan bagi remaja dan calon pengantin. Dan kegiatan intervensi gizi sensitif antara lain ; ketahanan pangan oleh Dinas Pertanian, pemenuhan sanitasi dan air bersih oleh Dinas Pekerjaan Umum melalui pemenuhan air bersih dengan pamsimas.[24] 


\section{Pembahasan}

Pada penelitian Norsanti, (2020) dampak kondisi pandemi covid-19 juga dirasakan pada upaya pencegahan stunting. Kegiatan intervensi gizi salah satunya yang dilakukan oleh kader PMT (Pemberian Makanan Tambahan) dengan memasak makanan tambahan untuk bayi dan balita stunting kemudian membagikannya pada bayi dan balita dengan cara dikumpulkan bersama pada saat pemberian makanan, akan tetapi karena kondisi pandemi covid orang tua takut untuk membawa keluar anak keluar rumah, sehingga makanan tambahan yang sudah dimasak di distribusikan dari rumah ke rumah bayi atau balita stunting. Kondisi tersebut memunculkan permasalah baru yaitu tenaga atau kader PMT kurang, yang sebelum pandemi satu desa hanya butuh 1 kader PMT. Kader PMT bertugas memberikan makanan 3 kali sehari selama 3 bulan selebihnya penyediaan makanan dan asupan gizi diserahkan pada orang tua masing masing. Kondisi pandemi covid -19 juga menyebabkan anggaran banyak terfokus pada pencegahan dan penyebaran covid.[15]

Hasil penelitian C.Rosha, et al (2016) menunjukan bahwa strategi penanggulangan permasalahan gizi adalah salah satu kerangka konsep yang dikembangkan UNICEF, dalam kerangka konsep menyebutkan bahwa masalah gizi disebabkan oleh penyebab langsung, penyebab tidak langsung dan akar masalah. Upaya untuk mengatasi masalah tersebut diperlukan kerjasama lintas sektor melalui intervensi gizi spesifik dan intervensi gizi sensitif. Intervensi gizi spesifik berkontribusi $30 \%$ untuk mengatasi stunting, sedangkan intervensi sensitif berkontribusi $70 \%$ dalam mengatasi stunting. Intervensi gizi spesifik yang dilakukan oleh sektor kesehatan, langsung pada sasaran yaitu; bayi, balita, remaja dan ibu hamil, dengan bentuk kegiatan upaya kesehatan bersumberdaya masyarakat (UKBM) seperti; posyandu yang didalamnya ada pelayanan kesehatan ibu dan anak, imunisasi dan stimulasi dini tumbuh kembang (SDIDTK), bina keluarga balita, kelas ibu hamil, pemberian tablet tambah darah untuk remaja putri, penanggulangan, pencegahan infeksi dan kecacingan pada bayi dan balita. Pada intervensi gizi sensitif banyak melibatkan lintas sektor melalui perbaikan sanitasi dan air bersih (kegiatan sanitasi berbasis masyarakat yaitu pembuatan jamban komunal),pembuatan lubang biopori untuk mencegah banjir, program pengentasan kemiskinan berupa bantuan tunai untuk masyarakat miskin, pemberdayaan perempuan berupa pelatihan dan pemberian bibit tanaman, peningkatan ketrampilan dan pengetahuan tentang pola asuh dan gizi untuk ibu hamil dan bayi.[16]

Penelitian tersebut sejalan dengan penelitian N.Probohastuti, D.Rengga, (2019) yaitu intervensi gizi sensitif dengan beberapa kegiatan yang melibatkan banyak sektor antara lain dengan peningkatan dan penyediaan akses air bersih dan sanitasi, peningkatan akses gizi dan kesehatan serta KB yang berkualitas, program JKN, peningkatan akses pangan bergizi. Kegiatan harus dilaksanakansecara terkoordinasi atau sinergi. Kebijakan pemerintah kabupaten untuk penyediaaan air bersih dengan Program penyediaan air minum dan sanitasi berbasis masyarakat (PAMSIMAS) sudah dilakukan akan tetapi pada saat musim kemarau sumber air menjadi kering, sehingga pemerintah setempat segera mencari sumber air baru dan memberikan bantuan air bersih. Bantuan sanitasi berupa pembangunan jamban dengan dana desa dan kegiatan workshop STBM (Sanitasi Total Berbasis 
Masyarakat) akan tetapi pada kenyataan masih banyak masyarakat yang melakukan buang air besar sembarangan. Program JKN sudah berjalan dengan pemberian kartu KIS untuk masyarakat, akan tetapi masih ada beberapa masyarakat miskin yang belum mendapatkan KIS oleh karena pendataan yang kurang tepat sasaran. Pada kondisi ini upaya kedepan yang harus lebih giat dilaksanakan berupa penguatan kader dan kerjasama dengan masyarakat untuk perbaikan dan penyebar luasan informasi tentang stunting. [17]

Pada penelitian G.Muthia,et al (2020) Pembiayaan atau anggaran untuk program intervensi gizi spesifik belum dialokasikan secara khusus, ketersediaan dana dari BOK sudah cukup besar, akan tetapi sebaiknya ada alokasi yang dikhususkan untuk anggaran intervensi gizi. Pada sumerdaya disebutkan bahwa Sumber Daya Manusia terutama petugas gizi masih diperlukan penambahan petugas gizi untuk kegiatan posyandu terutama untuk pemantauan anak dengan gagal tumbuh (growth faltering). Perencanaan kegiatan didapatkan hasil bahwa perencanaan kegatan sama dengan tahun sebelumnya.[18] Berbeda pada penelitian syafrina, et al,(2018) bahwa perencanaan kegiatan di kabupaten padang pariaman dilakukan setiap tahun dengan mengidentifikasi permasalahan dan pencapaian tahun sebelumnya.[19]

Pada penelitian M.Syafrina, et al (2020) Anggaran program gizi masih belum mencukupi termasuk dana anggaran untuk pencegahan stunting masih belum tersedia sehingga kegiatan belum berjalan maksimal. Pemerintah melakukan advokasi kepada DPRD dan pemerintah daerah untuk mendapatkan dukungan dana pencegahan stunting. Upaya yang dilakukan pemerintah dengan capaian sanitasi yang belum mencapai target yaitu dengan kegiatan ; pemicuan, penyuluhan, pemeriksaan kualitas depot air dan pemeriksaan air sumur masyarakat. Proses regulasi dapat erjalan lancer lancer jika didahului dengan advokasi dan sosialisasi kepada Bupati dengan tujuan menjelaskan masalah stunting.Perencanaan program gizi dilakukan dalam bentuk rencana kerja tahunan yang mengacu pada rencana strategis tahun 2013 - 2018. Perencanaan berdasarkan hasil analisis, identifikasi permasalahan dari evaluasi pencapaian program tahun brikutnya. [19]

Hasil pada penelitian tampubolon et al,(2020) sejalan dengan dengan penelitian permanasari et al, (2020) bahwa kegaiatan intervensi gizi sensitif belum sepenuhnya terintegrasi, sehingga perlu pemahaman yang sama agar dapat sepaham dan dimengerti oleh semua sektor. Kebijakan penurunan stunting sudah lama dituangkan melalui peraturan presiden No.42/2013 yaitu tentang gerakan nasional percepatan perbaikan gizi yang dapat dijadikan acuan pemerintah daerah untuk percepatan penurunan masalah gizi. Pada saat ini telah disususn strategi terbaru dalam penanggulangan stunting berupa strategi nasional atau starna s percepatan dan pencegahan stunting 2018 - 2024 yang sedang dilaksanakan pemerintah, salah satu pilarnya yaitu konvergensi program pusat, daerah dan sampai ke desa.[23]

\section{Kesimpulan}

Upaya pencegahan dan penanganan stunting terbagi menjadi intervensi spesifik dan sensitif. Intervensi gizi spesifik lebih banyak dilakukan oleh sektor kesehatan. Perencanaan kegiatan intervensi spesifik harus dilakukan sesuai dengan permasalahan yang ada dan hasil 
capaian program tahun sebelumnya, agar tujuan percepatan penurunan stunting lebih efektif tidak sekedar kegiatan atau program rutinitas. Keterbatasan anggaran yang terjadi, perlu di upayakan advokasi yang didukung oleh regulasi. Pada Masa pandemi covid seperti sekarang, anggaran lebih bayak digunakan untuk pencegahan dan penyebaran covid-19, namun upaya percepatan penurunan stunting masih menjadi prioritas oleh pemerintah. Pada pelaksanaan intervensi gizi sensitif kerjasama dan koordinasi perlu lebih diperkuat, di mulai sejak awal perencaaan kegiatan, pelaksanaan dan monitoring atau evaluasi. Ketersediaan data yang akurat dan terintegrasi sangat diperlukan dalam proses perencanaan penentuan suatu program kebijakan yang akan dilaksanakan. Semua sektor harus saling mendukung agar tidak terjadi ego sektoral sehingga timbul sinergisme dan pemahaman yang sama dalam upaya penanganan stunting. Upaya meningkatkan kesadaran masyarakat tentang pentinnya gizi juga menjadi tujuan dalam intervensi gizi. Kebijakan dan regulasi upaya penanganan stunting yang dilkeluarkan pemerintah pusat seharusnya ditindaklanjuti dengan regulasi oleh pemerintah daerah dan dapat dilaksanakan sampai ke tingkat bawah yaitu desa. Keterpaduan upaya pencegahan dan penanganan stunting harus selaras dari tingkat pusat, daerah sampai pada tingkat desa baik intervensi gizi spesifik maupun intervensi gizi sensitif.[2]

\section{Referensi}

[1] Kemenkes RI, "Buletin Stunting," Kementeri. Kesehat. RI, vol. 301, no. 5, pp. 1163$1178,2018$.

[2] E. Satriawan, "Strategi Nasional Percepatan Pencegahan Stunting 2018-2024," no. November, pp. 1-32, 2018.

[3] L. S. Nisa, "Kebijakan Penanggulangan Stunting Di Indonesia," vol. 13, no. 2, pp. 173-179, 2018.

[4] V. F. Binar pamungkas, Suprianto,Usman, Roos Nana Sucihati, "Penggunaan Dana Desa Pada Masa Pandemi Covid-19 Di Kabupaten Sumbawa," J. Soc. Sci.

Humanit., vol. 21, no. 1, pp. 1-9, 2020.

[5] E. H. Himawati and L. Fitria, "Hubungan Infeksi Saluran Pernapasan Atas dengan Kejadian Stunting pada Anak Usia di Bawah 5 Tahun di Sampang," J. Kesehat. Masy. Indones., vol. 15, no. 1, p. 1, 2020, doi: 10.26714/jkmi.15.1.2020.1-5.

[6] F. A. Dhiah, "KUalitas pelayanan antenatal oleh bidan di Puskesmas Kabupaten Purbalingga," Universitas Indonesia, 2010.

[7] J. H. Humphrey et al., "The sanitation hygiene infant nutrition efficacy (SHINE) Trial: Rationale, design, and methods," Clin. Infect. Dis., vol. 61, pp. S685-S702, Dec. 2015, doi: 10.1093/cid/civ844.

[8] H. M. Fenta, D. L. Workie, D. T. Zike, B. W. Taye, and P. K. Swain, "Determinants of stunting among under-five years children in Ethiopia from the 2016 Ethiopia demographic and Health Survey: Application of ordinal logistic regression model using complex sampling designs," Clin. Epidemiol. Glob. Heal., 2019, doi: 10.1016/j.cegh.2019.09.011.

[9] J. Lee, R. F. Houser, A. Must, P. P. De Fulladolsa, and O. I. Bermudez, "Disentangling nutritional factors and household characteristics related to child stunting and maternal overweight in Guatemala," Econ. Hum. Biol., vol. 8, no. 2, pp. 188-196, 2010, doi: 10.1016/j.ehb.2010.05.014. 
[10] E. Kusumawati, S. Rahardjo, and H. P. Sari, "Model Pengendalian Faktor Risiko Stunting pada Anak Usia di Bawah Tiga Tahun," J. Kesehat. Masy., vol. 9, no. 3, pp. 249-256, 2013.

[11] Kementrian Kesehatan RI, "RISKESDAS 2018. Jakarta;," vol. 44, no. 8, pp. 1-200, 2018, doi: 10.1088/1751-8113/44/8/085201.

[12] Candarmaweni and A. Y. S. Rahayu, "Tantangan Pencegahan Stunting Pada Era Adaptasi Baru 'New Normal' Melalui Pemberdayaan Masyarakat Di Kabupaten Pandeglang the Challenges of Preventing Stunting in Indonesia in the New Normal Era Through Community Engagement," J. Kebijak. Kesehat. Indones. JKKI, vol. 9, no. 3, pp. 136-146, 2020, [Online]. Available: https://journal.ugm.ac.id/jkki/article/view/57781.

[13] A. S. Samsudrajat et al., "Kebijakan Penyelamatan 1000 Hari Pertama Kehidupan (1000 HPK) dan Penurunan Stunting di Kota Semarang," 2018.

[14] P. Daerah, P. M. Desa, P. D. Tertinggal, P. D. Tertinggal, M. Desa, and P. D. Tertinggal, "Permendes Pembangunan daearah tertinggal dan Transmigrasi No.14 Th. 2020," pp. 1-41, 2020.

[15] N. Norsanti, "EFEKTIVITAS PROGRAM PERCEPATAN PENURUNAN STUNTING DI KEGAMATAN BATUMANDI KABUPATEN BALANGAN (Studi Kasus Pada Desa Mampari dan Desa Banua Hanyar)," J. Adm. Publik dan Pembang., vol. 3, no. 1, p. 10, 2021, doi: 10.20527/jpp.v3il.3825.

[16] B. Chistina Rosha, "Peran Intervensi Gizi Spesifik dan Sensitif dalam Perbaikan Masalah Gizi Balita di Kota Bogor," 2016.

[17] N. F. Probohastuti, D. A. Rengga, and M. Si, "IMPLEMENTASI KEBIJAKAN INTERVENSI GIZI SENSITIF PENURUNAN STUNTING DI KABUPATEN BLORA." [Online]. Available: http://fisip.undip.ac.id.

[18] G. Muthia, E. Edison, and E. Yantri, "Evaluasi Pelaksanaan Program Pencegahan Stunting Ditinjau dari Intervensi Gizi Spesifik Gerakan 1000 HPK Di Puskesmas Pegang Baru Kabupaten Pasaman," J. Kesehat. Andalas, vol. 8, no. 4, pp. 100-108, 2020, doi: 10.25077/jka.v8i4.1125.

[19] M. Syafrina, "Artikel Penelitian Analisis Komitmen Pemerintah Kabupaten Padang Pariaman dalam Mengatasi Masalah Stunting Berdasarkan Nutrition Commitment Index 2018," vol. 8, no. 2, pp. 233-244, 2018.

[20] S. I. Prihatini D, "Implementasi kebijakan alokasi dana desa dalam upaya pencegahan stunting terintegrasi (," vol. 4, no. 2, pp. 1-14, 2020.

[21] N. H. Putri EN, "Collaborative Governance Dalam Penanggulangan Stunting Di Desa Kalirandu Kecamatan Petarukan Kabupaten Pemalang," 2020.

[22] D. Tampubolon, "Kebijakan Intervensi Penanganan Stunting Terintegrasi," J. Kebijak. Publik, vol. 11, no. 1, p. 25, 2020, doi: 10.31258/jkp.11.1.p.25-32.

[23] Y. Permanasari et al., "Tantangan Implementasi Konvergensi pada Program Pencegahan Stunting di Kabupaten Prioritas," Media Penelit. dan Pengemb. Kesehat., vol. 30, no. 4, pp. 315-328, 2020, doi: 10.22435/mpk.v30i4.3586.

[24] W. Sutraningsih, J. Marlindawani, and ..., "Implementasi Strategi Pelaksanaan Pencegahan Stunting di Kabupaten Aceh Singkil Tahun 2019," J. ..., vol. 7, no. 1, pp. 49-68, 2021, [Online]. Available:

http://www.jurnal.uui.ac.id/index.php/JHTM/article/view/1390. 